\title{
Smart library services: Trends, opportunities and challenges for school library professionals during the pandemic
}

\author{
Rajesh Patel $^{1 *}$, Anitha B ${ }^{2}$ \\ 1,2Librarian, ${ }^{1}$ Bharatiya Vidya Bhavan's GIPCL Academy, Gujarat, ${ }^{2}$ Vidyodaya School, Kochi, Kerala, India
}

*Corresponding Author: Rajesh Patel

Email: rforraj@rediffmail.com

\begin{abstract}
The whole world is facing an unforeseen crisis due to the COVID 19 pandemic. The education sector too is not free from its impact. School library professionals faced unpredicted challenges during this time. As physical learning in schools came to a stand-still, teaching- learning process moved from classrooms to personal spaces. As education became deranged, some schools provided access to remote learning via internet and other technological tools. But technological and socio-economic barriers made online education an uncharted territory for a good number of schools in our country. Most of the library professionals rose to the occasion. Working in a quick pace, providing all available resources to support both teachers and students, technology became a saviour to librarians in every nook and corner of our country. This study mainly focused on those who have not compromised with challenges posed by the pandemic. The paper presents an outline of the significant makeover that happened to school libraries and how school librarians, with the help of various technological tools provided a virtual support to their patrons in an excellent manner. The paper tries to suggest some possible solutions on how to provide more efficient library service in future.
\end{abstract}

Keywords: Online Education, Remote Learning, School Library, Technology in Libraries, Virtual Library services.

\section{Introduction}

The Covid-19 pandemic has hit the entire education system of the whole world in a furious manner. It was a unique and unprecedented challenge to the stakeholders of education. School Libraries as integral part of the education system, always strive to support academic community. The impact of this pandemic is severe on libraries too. Due to frequent lockdowns a shift in the pattern of library services has been witnessed. The academic community found it difficult to access required resources or course materials and started seeking remote access to authentic information sources. Though it has been a big challenge for librarians to support the education system in such a constantly changing environment, smart librarians took it as their moral responsibility and found new opportunities in it. Embracing new technology was the only way out to resilience. Collaborative work among School Librarians witnessed a strong progress. They united through social media platforms to share their expertise and resources. This helped them to explore more avenues for their professional growth. Collaborations with student-teacher communities helped them to respond to the rapidly evolving situations by constantly monitoring the requirements. Librarians took this as an opportunity to share, learn, grow and strengthen themselves. It helped them to enhance their knowledge, skills and proficiency with diverse tools and techniques. This paper evaluates how School Librarians around the globe immediately adopted innovative and creative methods harnessing the endless possibilities of technology to deliver their services effectively. It aims to a valuable material for school library professionals, educators, policy makers, teachers, students, researchers, and information professionals working in the field of school education for future references. The paper identifies the face-shift happened to libraries, the new role taken up by the librarians to clasp the new- normal pattern, social media and digital platforms utilised for sharing resources and how scholarly communication is taking place uninterruptedly and to give some possible solutions for providing more efficient library service in future.

\section{Literature Reviews}

Here, the authors tried to review a few studies published earlier about how library services were carried out systematically during a crisis situation.

Kammer and Burress (2020) conducted a study on School Librarian's Questions about Remote Instruction: Opportunities for LIS Educators. School Library professionals bowed to social media during the COVID-19 pandemic as a handy tool for interacting with their peers, to extend library instruction and access resources remotely. With the help of social networks School Librarians were able to work remotely, although they had many queries associated with digitization, digital policy, and digital ethics. This work after comparing with the recent LIS curriculum provides a discourse with analysis on such issues while providing services and resources online. The findings of the study were and will be helpful to develop skills to promote online library services.

Asif and Singh (2020) have explored the Trends, Opportunities and Scope of Libraries during Covid-19 pandemic. Technological advancements has revolutionized library services a lot. Virtual Libraries has become more competent in areas of resource sharing and digitalization. Users are seeking precise and prompt digital information and this require expertise of skilled library professionals. This paper throws light on the needs and opportunities to learn new tools and technologies to bring out optimal use of online resources and services during such unprecedented setbacks. It also provides an outline on current trends and preventive 
measures to be planned for libraries to serve proactively during the present as well as post pandemic situation.

AASL (2020) has given an elaborate study on School Librarians role to support learning during the pandemic. This study mainly focus on the versatile roles played by a School Librarian like that of an instructional partner, teacher, leader, information specialist and program administrator. This article also describes school librarians' role in different learning conditions and prove their competency in face to face learning, blended learning and distance learning for creating an inclusive learning environment. In the current challenging situation schools definitely require the service of such empowered and competent librarians who have skills to spontaneously meet the learner demands.

Ishtiaq, Sehar and Shahid (2020) have surveyed on Information Dissemination during Covid-19 and Lockdown: The Role of University libraries of Sindh, Pakistan. The infectious virus transformed libraries from traditional to online mode. The core objective of this research was to find how services and instructional programs were provided by libraries and to highlight the tools used by librarians in collecting and disseminating information during this pandemic. The data for the study was collected online and analysed with the help of SPSS (Statistical Package for Social Sciences) software. The study found that library professionals are always ready for new challenges, but need more training programmes to enhance their digital skills.

Chakraborty K, Kureshi, Gajbe, Upadhyay N. and Dalimi Devi (September 2020) tried to analyse the Role of LIS Professionals to provide authentic information sources during COVID-19 Pandemic. They have done this research study by analysing the pandemic situation, collecting data from authentic information sources like official Government of India portals, National/International agencies and Scopus abstracting databases. Here librarian's services in finding authentic and trustworthy information sources has been identified as vital for carrying out uninterrupted research, where most of the researchers depend hugely on online sources. Librarians need to guide the users regarding what is available online, how to find authentic sources and how to get exact information without much wastage of their time.

\section{Objectives of the study}

The main intend of this study is to create awareness among library professional to cope-up with new challenges, the need to work proactively and rise up to the expectations of their parent institutions which reflects their professional commitment and passion towards work. For this they need to:

1. Explore new online tools and technique to serve users.

2. Offer user awareness services periodically

3. Discover innovative ways to motivate and reconnect library users

4. Find new opportunities from current challenges

5. Develop persistent professional learning skills

\section{Scope and Limitation of the study}

This study recognizes School Library as knowledge hubs providing authentic and up-to-date information with the expertise of library professionals utilising the possibilities of information technology. The technological advancements has modernized traditional libraries to the smart libraries and School Librarians have emerged as tech-savvy people converting challenges to opportunities. During the pandemic many librarians adapted new and innovative ways to reach out and serve their users and the functions of libraries shifted to digital mode. This study will spotlight the various educational tools, communication channels, e-resources, digital/ virtual libraries and e-learning methods customized by School Librarians for the optimum utilization of library resources. But the study is limited to the opinion of 220 librarians who responded positively to the survey which is only a small percentage of the entire librarian community in our country. Some responses may not be completely factual as there are official restrictions on revealing the details of the school system. Though the paper suggests some possible solutions to improve the system, such things are largely dependent on technological and socio- economic factors.

\section{Methodology}

An online survey was conducted among School Librarians working in different states of India. To conduct the survey an online tool- "Google Form", which is one of the best tools for online survey was used. The target population was School Library Professionals and for this 500 Librarians were selected from Schools across India. Researchers examined several websites developed by School Librarians to get the requisite data and a telephonic conversation also was done. Microsoft word and excel have been used for data collection, analysis, interpretation and presentation.

\section{Data Collection and Analysis}

Researchers have conducted a survey for the school library professionals. For this a Google Form link was shared with them through different WhatApp groups and personally too. The Google form link was shared with around 500 school library professionals and out of them 220 responded. That means response rate is $44 \%$. During personal conversations the researchers found that many of them lost their jobs due to the pandemic and some of them revealed that they are not allowed to share such official information.

Here the researchers have considered 220 responses as study data and based on that analysis has taken place. It is found that out of 220 schools, 213 i.e., $97 \%$ are conducting online classes for their students while only $7 \%$ are not conducting it. The following chart shows the different platforms which are used to conduct the online classes.

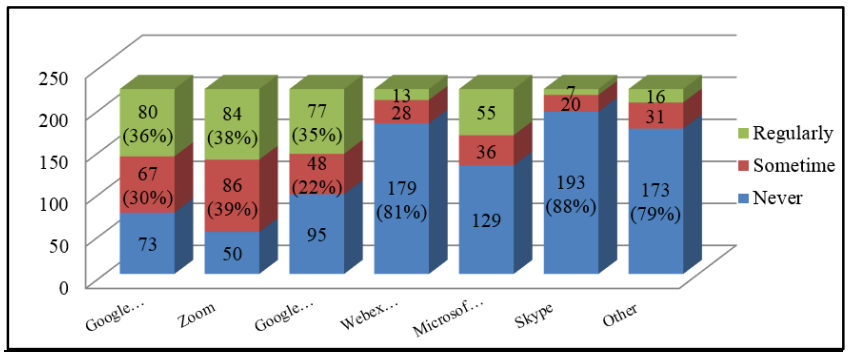


Fig. 1: Platforms used

From the above chart it is clear that for Google meet there are $36 \%$ regular users among the librarian community, $30 \%$ use it occasionally, and the rest use it quite rarely. Zoom meet: $38 \%$ regular users, $39 \%$ occasional users and $22 \%$ never use it. Google Classroom: 35\% regular users, 22\% occasional users and $43 \%$ never use it. Webex Virtual Classroom: $81 \%$ never use it and the rest comes under the category of regular or occasional users. Microsoft Teams: $26 \%$ regular users, $17 \%$ occasional users and the rest $59 \%$ never use it. Skype: less than $1 \%$ use it regularly, $2 \%$ use it occasionally and the rest never use it. So majority of librarians use either Google Meet or Zoom or Google Classroom platforms regularly.

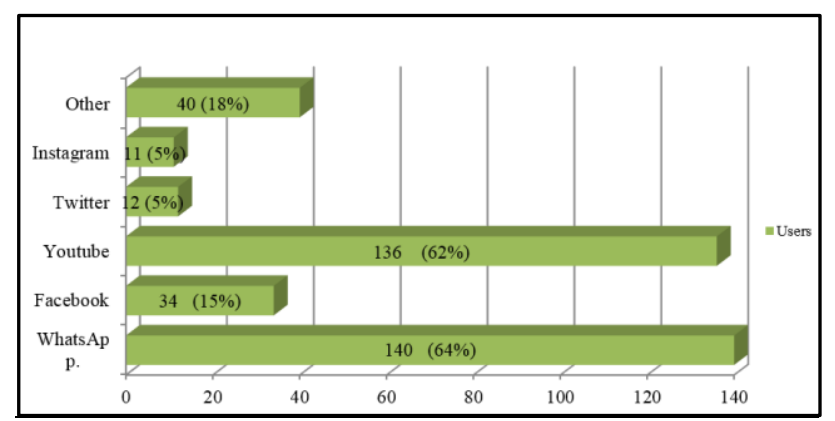

Fig. 2: Use of Social Media Platform

Among social media platform services used by Librarians to give links or other services, outube and Whatsapp tops with $62 \%$ and $65 \%$ respectively. Facebook, Twitter, Instagram and other platforms comes under $18 \%$ only in their use.

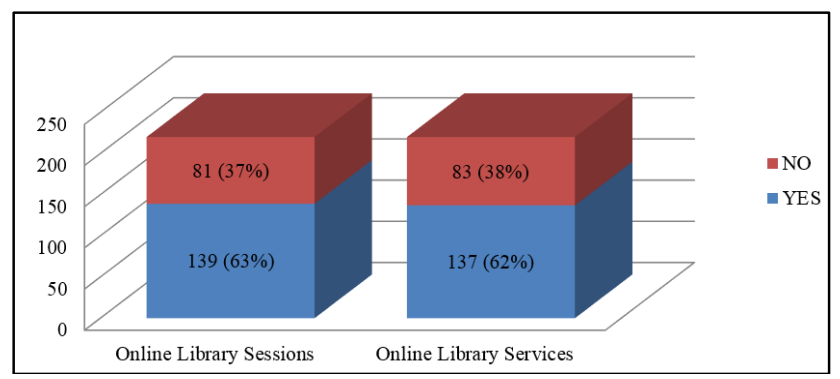

Fig. 3: Online library classes \& services

This figure shows that majority of the School Librarians provide online library sessions and online library services for their patrons. But there are librarians (about 37-38\%) who are yet to provide their services through online mode.

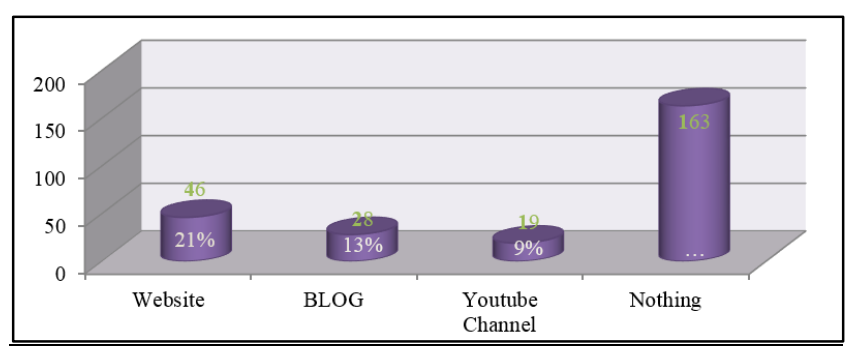

Fig. 4: Library Have it's Own

Most of the School Library Professionals does not have a communication channel like YouTube, website or blog. Less than $20 \%$ are acquainted with such facilities.

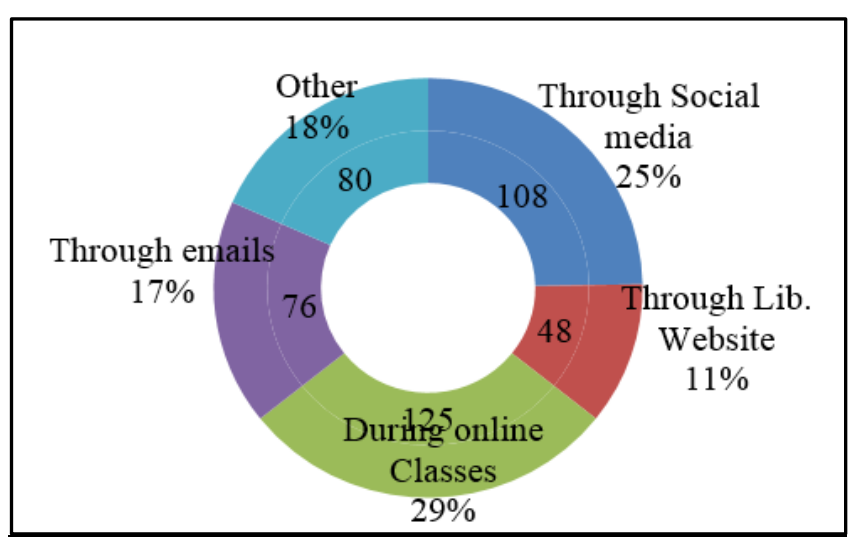

Fig. 5: Library Serve Through

This figure indicates that $29 \%$ of the School Librarians provide their services and resources/ links for resources to users during online sessions, $25 \%$ through social media, $17 \%$ through emails, $11 \%$ through their websites and $18 \%$ use other modes.

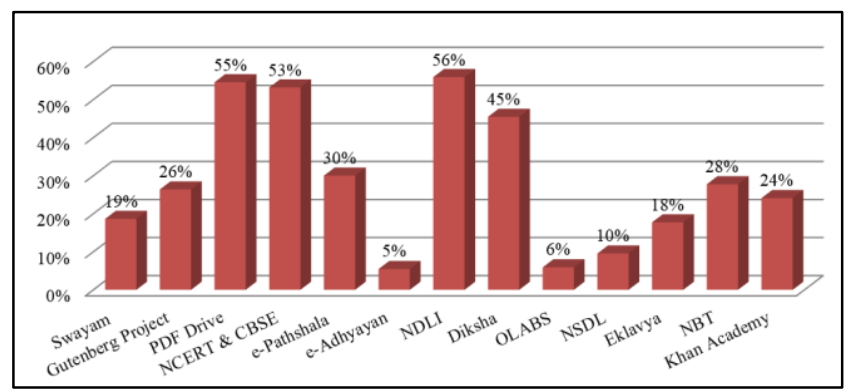

Fig. 6: Online Resources

Most number of School Librarians depends upon PDF drive, NCERT \& CBSE resources, National Digital Library and Diksha for providing resources. A small percentage of School Librarians also use Swayam, Gutenberg project, e- Pathsala, Ekalavy, National Book Trust and Khan Academy resources. 
Table 1: Awareness about the useful Technological Tools

\begin{tabular}{|c|c|c|c|c|c|c|c|c|c|}
\hline \multirow{3}{*}{$\begin{array}{c}\text { S. No. } \\
1\end{array}$} & \multirow{3}{*}{$\begin{array}{l}\text { Tools } \\
\text { Google Drive }\end{array}$} & \multicolumn{8}{|c|}{ Aware about the Tools } \\
\hline & & \multicolumn{2}{|c|}{ Don't Know } & \multicolumn{2}{|c|}{ Beginner } & \multicolumn{2}{|c|}{ Average } & \multicolumn{2}{|c|}{ Expert } \\
\hline & & 10 & $5 \%$ & 23 & $10 \%$ & 93 & $42 \%$ & 94 & $43 \%$ \\
\hline 2 & PDF Tools & 14 & $6 \%$ & 36 & $16 \%$ & 89 & $40 \%$ & 81 & $37 \%$ \\
\hline 3 & Google site & 21 & $10 \%$ & 36 & $16 \%$ & 89 & $40 \%$ & 74 & $34 \%$ \\
\hline 4 & Padlet, Wakelet \& Slido & 82 & $37 \%$ & 63 & $29 \%$ & 45 & $20 \%$ & 30 & $14 \%$ \\
\hline 5 & Google form & 15 & $7 \%$ & 50 & $23 \%$ & 68 & $31 \%$ & 87 & $40 \%$ \\
\hline 6 & Nearpod & 138 & $63 \%$ & 50 & $23 \%$ & 19 & $9 \%$ & 13 & $6 \%$ \\
\hline 7 & Google Books & 54 & $25 \%$ & 54 & $25 \%$ & 75 & $34 \%$ & 37 & $17 \%$ \\
\hline 8 & Google doc, sheet, slide & 23 & $10 \%$ & 40 & $18 \%$ & 78 & $35 \%$ & 79 & $36 \%$ \\
\hline 9 & Mentimeter & 148 & $67 \%$ & 39 & $18 \%$ & 19 & $9 \%$ & 14 & $6 \%$ \\
\hline 10 & Video recorder and editor & 56 & $25 \%$ & 64 & $29 \%$ & 61 & $28 \%$ & 39 & $18 \%$ \\
\hline 11 & Graphic Designing tools & 119 & $54 \%$ & 60 & $27 \%$ & 25 & $11 \%$ & 16 & $7 \%$ \\
\hline 12 & E- Book creator & 111 & $50 \%$ & 50 & $23 \%$ & 36 & $16 \%$ & 23 & $10 \%$ \\
\hline 13 & Flip Grid & 125 & $57 \%$ & 55 & $25 \%$ & 24 & $11 \%$ & 16 & $7 \%$ \\
\hline 14 & Audio \& Video books & 26 & $12 \%$ & 59 & $27 \%$ & 72 & $33 \%$ & 63 & $29 \%$ \\
\hline 15 & $\begin{array}{l}\text { Creative Commons, OER } \\
\text { and Free to use resources }\end{array}$ & 89 & $40 \%$ & 46 & $21 \%$ & 55 & $25 \%$ & 30 & $14 \%$ \\
\hline 16 & Gamification tools & 142 & $65 \%$ & 40 & $18 \%$ & 27 & $12 \%$ & 11 & $5 \%$ \\
\hline & Average & 73.31 & $33 \%$ & 47.81 & $22 \%$ & 54.69 & $25 \%$ & 44.19 & $20 \%$ \\
\hline
\end{tabular}

From the above table it is evident that average among School Librarians are either beginners or not familiar with the various technological tools available. Among the expert users most of them are using Google tools, PDF tools or Audio/ Video books.

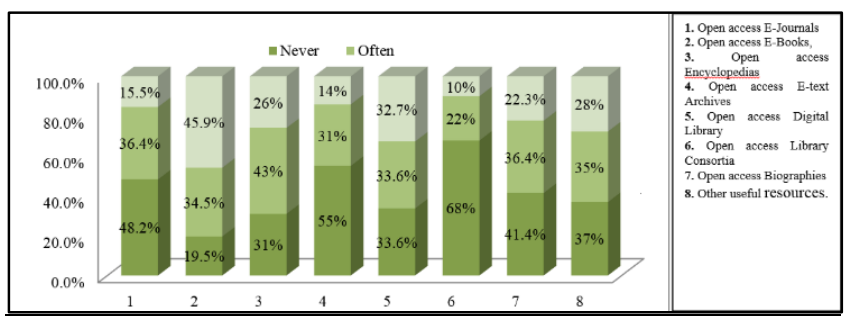

Fig. 7: Open Access Resources

During the study, it has been observed that a good percentage of the School Librarians are yet to utilise the Open Access Resources available online. At the same time there is a small percentage that uses it occasionally. Among the occasional or regular users most of them use Open Access E- Books and Open Access Digital Libraries.

\section{Findings and Suggestions}

The results of this study have given a good picture of how School Librarians tried to support education during the pandemic by readily shifting to online modes. From the responses a clear idea was obtained about the tools and platforms employed to provide uninterrupted library services.

1. Around 97\% schools are conducting online classes which shows the commitment of teachers to provide quality education in difficult situations too. But less importance was given to libraries. Only 37 to 38 percent of the library professionals were allowed to conduct online sessions or provide online library services. If more library sessions are provided, the student- teacher community will get extra awareness about the effective utilization of available online resources.

2. To conduct online classes most School Librarians found Zoom, Google Meet and Google Classroom as convenient and handy platforms. Whatsapp and YouTube are the social media channels used frequently to provide information. Most of the librarians are providing resources during online sessions only. Hardly $20 \%$ of library professionals apply Website, BLOGS and YouTube Channel tools for information dissemination. Use of communication channels need to be popularized among library professionals.

3. $67 \%$ of the library professionals are aware about the various useful technological tools as beginner, average user or experts. But for some reasons they are unable to apply it. Those library professionals who lag behind in utlilising the immense possibilities of technology should learn to apply it maximum by collaborating with other School Librarians who are technically very advanced.

4. Technological tools like e-book creator, pdf tools, Flip Grid, Mentimeter, Padlets, Nearpods, Slido along with various Gamification tools need to be employed in libraries to make library sessions more interactive and fruitful.

5. Most of the professionals make use of the online resources like National Digital Library of India, Diksha Portal, PDF Drive, NCERT and CBSE sites, although much more of these kind are available freely. Use of the above mentioned resources too are only to a very limited 
extend. More of these kinds are to be explored and utilized for better services.

6. Very less number of School Librarians are aware about OER and use of Open access Resources. Librarians should proactively provide all those Open Educational Resources and Open Access Resources readily available in the web. School Library professionals need to get more training in this direction.

7. The School Library professionals must be able to design their services in such a way that all the users can avail the library facilities virtually. Uninterrupted library services are inevitable for all academic institutions.

\section{Conclusion}

School Librarians need to embrace technological tools in a faster pace thereby readily connecting users with information. They have to provide digital resources and technical support to users as an urgent need of the hour. The points discussed in this paper are helpful to School Librarians for future planning and sound decision making. It is high time that School Librarians should recognise the need to build a strong e-platform to render their services. They should realise that adopting holistic approach based on latest technology is the only way out which can help win the challenges and keep the libraries functioning without a halt. School Librarians need to convert such challenges to opportunities and create a new face of knowledge hubs strong enough to support our educational system strive towards excellence even in adverse situations.

\section{Conflict of Interest}

The authors declare that there are no conflicts of interest in this paper.

\section{Source of Funding}

None.

\section{References}

1. Chakraborty K, Kureshi P, Gajbe SL, Sagar B, Upadhyay N, Devi D et al. Role of LIS Professionals to provide authentic information sources during COVID-19 a Pandemic crisis\&quot;. Library Philosophy and Practice (2020) 4180.

2. Sadia I, Naveed S, Attya S. Information Dissemination during Covid-19 and Lockdown: The Role of University libraries of Sindh, Pakistan \& quot; Library Philosophy and Practice (2020):4280.

3. Kammer J, Burress R. “School Librarian's Questions about Remote Instruction: Opportunities for LIS Educators" ALISE 2020 Proceedings, pp. 203-10.

4. Bhati P, Kumar I, Role of Library Professionals in a Pandemic Situation like COVID-19. Int J Libr Inf Stud. 2020;10(2):3348.

5. Das S, Verma MK. Role of Library and Information Professionals During Coronavirus (Covid-19) Pandemic. $J$ Transition Transformation. 2021:187-97.

6. Asif M, and Singh KK, Trends, opportunities and scope of libraries during Covid-19 pandemic. Indian J Libr Sci Inf Technol. 2020;5(1):24-7.

7. Dhamdhere SN, Digital Library Services and Practices: an online survey. Int J Libr Sci. 2012:6(2):65-75.

8. Dold CJ. The Role of Librarians in Academic Success. Sys Cybernetics and Inf. 2013;11(2):1-5.

\section{Websites}

1. https://www.sciencedirect.com/science/article/pii/S23 52771420302810

2. https://digitalcommons.unl.edu/cgi/viewcontent.cgi?a rticle $=8403 \&$ context $=$ libphilprac

3. https://www.slj.com/?detailStory=ahead-of-thecurve-school-librarians-innovate-take-on-newresponsibilities-SLJ-covid-19-survey

4. https://www.researchgate.net/publication/342697905 _Role_of_Library_Professionals_in_a_Pandemic_Sit uation_Like_COVID-19_Pankaj_Bhati

How to cite: Patel R, Anitha B. Smart library services: Trends, opportunities and challenges for school library professionals during the pandemic. IP Indian J Libr Sci Inf Technol. 2021;6(1):45-9. 